\title{
RADIONUCLIDE AND METAL BIOREMEDIATION FROM AQUATIC ENVIRONMENT BY ALGAE
}

\author{
Magda A. Shafik \\ Department of Biological and Geological Sciences, Faculty of Education, \\ Alexandria University.
}

\begin{abstract}
Three element were chosen for this investigation, radioactive carbon ${ }^{14} \mathrm{C}$ in form of ${ }^{14} \mathrm{C}$-urea and two element; chromium III and cobalt to study their biosorption and desorption mechanisms by two algal species; Sargassum linifolium and Dunaliella salina, in relation to their surface area. Active transport was the mechanism for ${ }^{14} \mathrm{C}$, Co and $\mathrm{Cr}$ uptake by the two algal species. Sargassum showed higher accumulation ratios than living algal cells; the reverse was true for Dunaliella. The antagonistic action between metal ions (radionuclide) binding to different algal cell surface was obtained by mixing ${ }^{14} \mathrm{C}$ with $\mathrm{Cr}$ and ${ }^{14} \mathrm{C}$ with $\mathrm{Co}$ in living algal cells of the two tested algae, while synergistic action was obtained by mixig $\mathrm{Cr}$ and $\mathrm{Co}$ in the living algal species. Noninteractive action was shown by mixng ${ }^{14} \mathrm{C}$ with $\mathrm{Cr}$ or $\mathrm{Co}$ in dried algal material. ${ }^{14} \mathrm{C}$ uptake by living cells of Sargassum and Dunaliella ameliorated cell vitality; this effect was higher in Dunaliella than in Sargassum. Chromium showed adverse effect than cobalt, both $\mathrm{Co}$ and $\mathrm{Cr}$ altered the metabolic pathway of chlorophyll formation. Siderophore formation increased the adsorption power of algal cell-wall especially Sargassum alga. The biosorption effect of these radionuclides was due to surface characteristics. Desorption mechanism was fast from Sargassum surfaces, while it was slower in Dunaliella. Dried Sargassum can be used successfully for bioremediation of ${ }^{14} \mathrm{C}$, $\mathrm{Co}$ and $\mathrm{Cr}$ from the contaminated sea water (even, at low concentration) up to five elution times, while living Dunaliella could be used for the removal of these elements from lakes. To ameliorate the adsorptive power of dried Sargassum, its surface area must be increased and the media must be iron-free.
\end{abstract}

\section{Introduction}

Along the Mediterranean coasts, a number of nuclear energy reactors have been established in France, Spain ...etc. Nuclear reactors release gaseous radioisotopes, mainly ${ }^{3} \mathrm{H},{ }^{14} \mathrm{C},{ }^{133} \mathrm{I}$ and ${ }^{135} \mathrm{I}$ and liquid effluents containing mainly ${ }^{3} \mathrm{H}$ (Halim, 1987). Aqueous effluents produced during nuclear power and defense activities frequently contain radionuclides. These effluents obtained from various sources, including reactor coolant water, evaporator condensate and fuel reprocessing wastes. Metal contained within these wastes include mainly the fission product strontium ${ }^{90} \mathrm{Sr}$ and caesium ${ }^{137} \mathrm{Cs}$ which possess particular health hazards. In addition, about nine radioactive metals enter the Suez Canal and Mediterranean Sea either directly or indirectly and cause radioactive pollution to the marine environment (Gazso, 2001). 
According to radiation hazards, several international and national organizations have established to set of guidelines for the safe handling of radioactive materials. The recommendations include: the maximum permissible dose, principles of radiation protection, personal monitoring, survey meters and waste disposal (Saleh, 1987). In this investigation, radionuclide wastes bioremediation from the marine environment was studied.

Among the aquatic food chains, algae may absorb radioisotopes from the aquatic environment, both ionic and particulate forms of radionuclide, and both passive and active mechanisms of uptake may be involved.

In natural waters, the uptake of a given isotope in relation to other fission products may be quite different from that on land. For example, planktonic algae were found to accumulate ${ }^{144} \mathrm{Ce}$ to a much greater extent than ${ }^{137} \mathrm{Co}$, whereas for land plants the reverse is true (Rice and Willis, 1959).

Observations of surface adsorption were firstly discussed in 1949 by Spooner; this adsorption is recently known as biosorption (surface adsorption). Once occurred, such radioisotopes may be more or less firmly bound or readily eluted. For example nitrosyl ruthenium apparently can form nonexchangeable complexes involving colloidal iron on the surface of diatom cells, although in the absence of iron, this does not occur (Jones, 1960). This phenomenon is recently known as siderophore.

Application of biotechnology for the treatment of various forms of radionuclides liquid wastes has many advantages such as; environment friendliness, self-reproducibility and adaptability, recycling of bio-products, specificity and good cost benefit ratios (Gazso, 2001).

In this investigation three of the hazards nuclide found in the aquatic environment was chosen, viz: cobalt (Co), chromium ( $\mathrm{Cr}$ III) and radioactive carbon $\left({ }^{14} \mathrm{C}\right)$. Biosorption and desorption of these radionuclide, by the marine macroalga Sargassum linifolium as representative for marine environment and Dunaliella salina, the unicellular alga as representative for lakes environment in relation to their surface area, were investigated. Also, the effect of these radionuclide on cell activities, in addition to siderophores production were also investigated, aiming to find safe, economic and practical mechanism for radionuclide removal with the recycling of biosorbant either from marine environment or from lakes.

\section{Materials and Methods}

\section{Algae materials}

Sargassum linifolium (Phaeophyta) was collected from Abu Qir locality in Alexandria. Ten grams fresh weight samples were washed thoroughly with sterilized distilled water several times and bacterial detection was carried out as described by Bekheet and Syrett (1977). Fresh samples of S. linifolium used as biosorbant were transferred to flasks containing $50 \mathrm{~mL}$ medium prepared as 
described by Shaban (1981). ${ }^{14} \mathrm{C}$-urea, chromium sulphate $\left(\mathrm{Cr}_{2}\left(\mathrm{SO}_{4}\right)_{3}\right)$ and cobalt chloride $\left(\mathrm{CoCl}_{2}\right)$ were added (individually) to this living material and deionized water was used for media preparation.

Dried samples of $S$. linifolium were prepared (in parallel with the fresh samples) by drying in an oven at $60^{\circ} \mathrm{C}$, then ground to a size in range of 500$700 \mu \mathrm{m}$ and stored in a desiccator.

The unicellular alga, Dunaliella salina (Chlorophyta), was the second biosorbant alga used in this investigation. It was obtained from Lake Mariut of Alexandria, purified and identified according to Masjuk (1972). The alga was cultivated on MH medium described by Loeblich (1982). The cultures were maintained at $25^{\circ} \mathrm{C}$ under light intensity of 4000 lux and aerated with sterilized air enriched with 5 per cent $\mathrm{CO}_{2}$ for 12 days. The algal cells were harvested at the mid of the exponential phase of growth, subjected to starvation for 24 hours, then diluted to give a suspension containing $7 \times 10^{6}$ cell $\mathrm{mL}^{-1}$ (Bekheet et al., 1984). At each sampling time, the algal suspension was filtered through the GF/C glass microfilter. The supernatents were discarded and the remaining filter discs with the pellet (cells) were subjected for measuring the tested metal or ${ }^{14} \mathrm{C}$. Dried Dunaliella cells were prepared as for Sargassum.

\section{Radionuclide preparation}

Radionuclide $\left({ }^{14} \mathrm{C}\right.$-urea), and chromium or cobalt were added to flasks containing fresh Dunaliella or Sargassum as well as to dried algal cells of both algae. Heavy metal concentrations $(5-15 \mathrm{mg} / \mathrm{L})$ were added by filtration to the sterilized stock medium through $0.2 \square \mathrm{m}$ nitrocellulose membrane of $\mathrm{K}_{2} \mathrm{Cr}_{2} \mathrm{O}_{7}$. The flasks were agitated at $200 \mathrm{rpm}$ and $25^{\circ} \mathrm{C} \pm 2$ in rotatory shaker, irradiance $(200$ $\left.\mathrm{mol} / \mathrm{m}^{-2} \mathrm{~s}^{-1}\right)$. The $\mathrm{pH}$ of the flasks was adjusted at 5 and the flasks kept for 10 hours or 36 hours incubation periods then filtered through $0.45 \square \mathrm{m}$ membrane filters and finally acidified and kept for analysis using the method described by Valdmar and Leite (2000). Control experiments were carried out simultaneously.

Cobalt, chromium and ${ }^{14} \mathrm{C}$-urea were introduced to stock medium singly as well as in mixture: ${ }^{14} \mathrm{C}$ plus $\mathrm{Co},:{ }^{14} \mathrm{C}$ plus $\mathrm{Cr}$ and $\mathrm{Cr}$ plus $\mathrm{Co}$; the second treatment was injected after 1 hour of injecting the first treatment. Experiments were stopped after 36 hour (Terry and Stone, 2002).

The radioactivity in pellet (living), residue (non-living) and filtrate of the two investigated algae was measured by Beckman LS 200B Liquid Scintillation Counter as described by Price (1983).

\section{Determination of sorption surface areas}

To calculate the surface area of Dunaliella salina algal cells (living and dried), the method described by Tien (2002) was used. The mean dimensions of the cell were measured by haemocytometer (assuming that algal shape approximates to a cylinder), and its surface areas were calculated by the equation: 
$2 \pi r(r+h)$, where: $\pi$ is a constant $=3.14$; $r$ is the radius of the cell and $h$ is the height. The total surface area per unit volume was calculated by multiplying the average surface area per unit cell by the total number of cells. The surface area of dried Sargassum material was also calculated from the mean dimension of the dried particles as mentioned above.

\section{Desorption of adsorbed radionuclide}

The algal material after treatment with radionuclide was introduced into $125 \mathrm{ml}$ Erlenmeyer flasks containing $100 \mathrm{ml}$ eluent. The flasks were shaked at 200 $\mathrm{rpm}$, then the samples were centrifuged and the total metal concentration was assayed for $\mathrm{Cr}$ and $\mathrm{Co}$ in eluent by atomic absorption spectroscopy and by Scintillation counter for ${ }^{14} \mathrm{C}$. Eluent used for this experiment were $\mathrm{CaCl}_{2}(0.05 \mathrm{M})$ in $\mathrm{HCl}$ for cobalt removal (Volesky and Kuyucak, 1988); $\mathrm{H}_{2} \mathrm{SO}_{4}(0.6 \mathrm{M})$ for chromium (Amorim et al., 2003); and $\mathrm{NaOH}(0.1)$ for ${ }^{14} \mathrm{C}$ (Vilar et al., 2007). All the desorption experiments were carried out in algal-packed columns with diameter / length ratio of 1/15 (Yang and Volesky, 1999).

The amount of adsorption $\left(\mathrm{Q}_{\mathrm{ads}}\right)$ and desorption $\left(\mathrm{Q}_{\mathrm{des}}\right)$ were calculated as described by Amorim et al. (2003) using the equations:

$$
\begin{gathered}
\mathrm{Q}_{\mathrm{ads}}=(\mathrm{Ci}-\mathrm{Cf}) \cdot \mathrm{V} / \mathrm{M} \\
\mathrm{Q}_{\mathrm{des}}=\mathrm{C}_{\mathrm{des}} . \mathrm{V} / \mathrm{M}
\end{gathered}
$$

Where: $\mathrm{Q}_{\mathrm{ads}}=$ Experimental amount of adsorption of element $(\mathrm{mg} / \mathrm{g})$,

$\mathrm{Q}_{\text {des }}=$ Experimental amount of desorption of element $(\mathrm{mg} / \mathrm{g})$,

$\mathrm{C}_{\mathrm{des}}=$ Concentration of desorbed metal $(\mathrm{mg} / \mathrm{l})$,

$\mathrm{Ci}=$ Initial concentration $(\mathrm{mg} / \mathrm{l})$,

$\mathrm{Cf}=$ Final equilibrium concentration,

$\mathrm{V}=$ Volume of solution (1),

$\mathrm{M}=$ weight of biomass ( $\mathrm{g}$ ).

\section{Siderophores formation and chlorophyll estimation}

Iron-deficient media for culturing Sargassum and Dunaliella was prepared as described by Neilands (1983). The effect of this deficiency on $\mathrm{Co}, \mathrm{Cr}$ and ${ }^{14} \mathrm{C}$-radionuclide adsorption was tested (relative to the control) and accumulation ratios were calculated. Chlorphylls were estimated according to Jeffrey and Humphrey (1975).

\section{Results and Discussion}

Active transport was the mechanism of ${ }^{14} \mathrm{C}, \mathrm{Cr}$ and $\mathrm{Co}$ uptake by both Sargassum linifolium and Dunaliella salina of this investigation, (Table 1), since the accumulation ratios of these nuclides under the low and high concentrations used exceeded 1.

Both Sargassum and Dunaliella used exhibited a number of metabolicdependent and metabolic-independent processes of uptake and accumulation of radionuclide (Gazso, 2001) and heavy metals (Gadd, 1990; Chaisukant, 2003 and 
Akhtar et al., 2004). The tendency of Sargassum (living and dried) to accumulate ${ }^{14} \mathrm{C}$ was greater than its tendency to cobalt and chromium (Table 1). Non-living algal material exceeded the living material by about 7 -fold in ${ }^{14} \mathrm{C}$ uptake; with both cobalt and chromium only 2 -fold was increased over the living material. High adsorptive power for dried cells was for ${ }^{14} \mathrm{C}$ and less efficiency was observed for chromium and cobalt treatments.

Table (1): Bioaccumulation of ${ }^{14} \mathrm{C}, \mathrm{Co}$ and $\mathrm{Cr}$ in Sargassum linifolium and Dunaliella salina in living materials and in dried cells. Values are percent of total concentrations used.

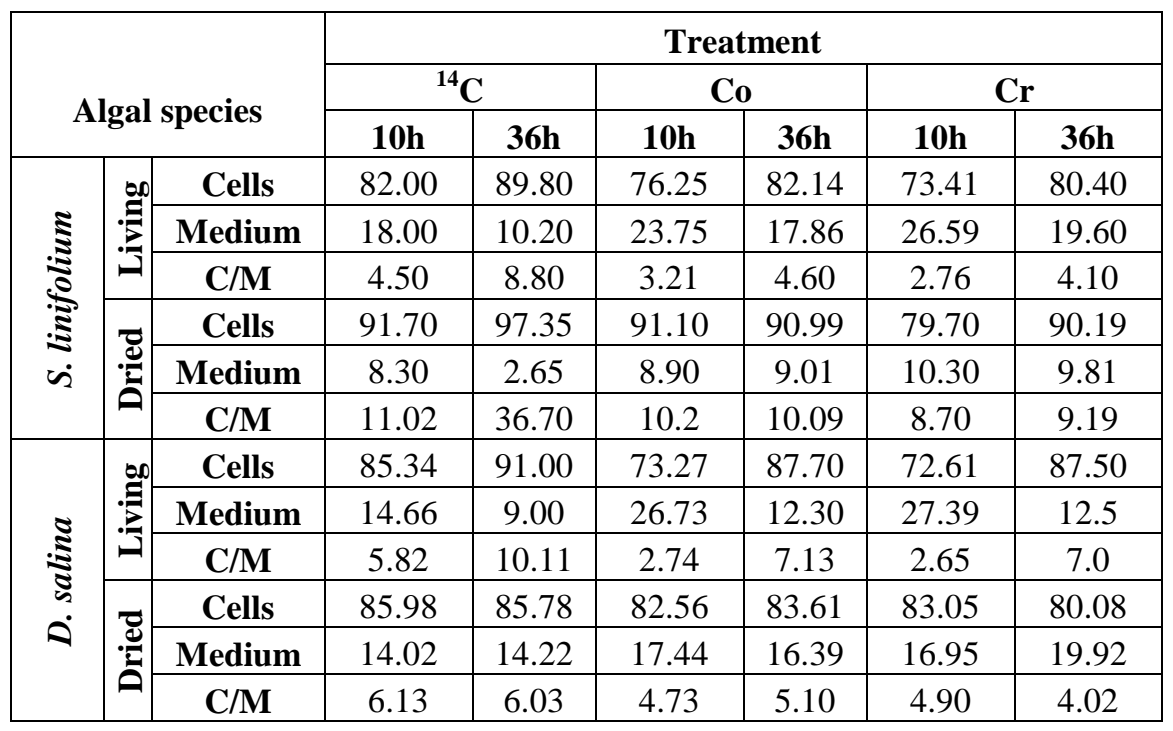

The difference in accumulation ratio between dried and in vitro cells of Sargassum was due to the large surface area of dried algal materials; the adsorptive power was high and accordingly the accumulation ratio was greater than in living algal materials. In the contrary, the accumulation ratio in living cells of Dunaliella exceeded that of the dried cells (Table 1). After 36 hour of incubation with either ${ }^{14} \mathrm{C}$, Co or $\mathrm{Cr}$, the accumulation ratio was about 3 -fold that after 10 hour incubation. In dried cells, the accumulation ratio was almost constant for each element within the 36 hour incubation period. In the unicellular algae, Chlorella vulgaris and Scenedesmus obliquus, dried algal cells had high adsorption power for metals at very low concentration, and to accumulate them with large quantities, via active transport (Centinkaya Donmez et al., 1999). Shafik and Alaa (1995) found that: living Scenedesmus obliquus removes large amounts of phosphorous from water by an active transport system.

Terry and Stone (2002) pointed out that living microalgae have an advantage to be used as biosorbant, due to metabolic uptake and continuous growth. They postulated that the microalga Scenedesmus abundans significantly 
outperformed dried algae in metal adsorption. Moreover, Pena-Castro et al. (2004) found that Scenedesmus incrassatulus adsorbed chromium VI efficiently by living cells because the uptake of chromate could be favored by actively growing alga. The results of this investigation agree with that of Pena-Castro (2004) for Dunaliella microalga.

In Sargassum, the accumulation ratio was higher when chromium was mixed with cobalt and with cobalt when mixed with chromium (about 2-fold) than when cobalt or chromium was present singly (Table 2). No significant difference was obtained when $\mathrm{Cr}$ was added prior to Co. When Co was added prior to ${ }^{14} \mathrm{C}$-urea, the accumulation ratio of ${ }^{14} \mathrm{C}$ was increased by $0.50 \%$ while, addition of ${ }^{14} \mathrm{C}$ prior to $\mathrm{Cr}$ decreased them. The effect of chromium (trivalent metal) on ${ }^{14} \mathrm{C}$ and Co was strongly marked; chromium ratio itself was ameliorated.

Table (2): Combined effect of ${ }^{14} \mathrm{C}, \mathrm{Cr}$ and $\mathrm{Co}$ on Sargassum linifolium and Dunaliella salina bioaccumulation (by either living or dried) algal materials. The first element was added 1 hour before the addition of the second element, and then incubated together for $36 \mathrm{~h}$.

\begin{tabular}{|c|c|c|c|c|c|c|c|c|c|c|c|c|c|c|}
\hline \multirow{3}{*}{\multicolumn{3}{|c|}{$\begin{array}{c}\text { Algal } \\
\text { species }\end{array}$}} & \multicolumn{12}{|c|}{ Treatments } \\
\hline & & & \multicolumn{2}{|c|}{$\begin{array}{l}{ }^{14} \mathrm{C} \text { prior } \\
\text { to } \mathrm{Cr}\end{array}$} & \multicolumn{2}{|c|}{$\begin{array}{c}\text { Cr prior } \\
\text { to }{ }^{14} \mathrm{C} \\
\end{array}$} & \multicolumn{2}{|c|}{$\begin{array}{l}{ }^{14} \mathrm{C} \text { prior } \\
\text { to Co }\end{array}$} & \multicolumn{2}{|c|}{$\begin{array}{c}\text { Co prior } \\
\text { to }{ }^{14} \mathrm{C} \\
\end{array}$} & \multicolumn{2}{|c|}{$\begin{array}{c}\text { Co prior } \\
\text { to } \mathrm{Cr} \\
\end{array}$} & \multicolumn{2}{|c|}{$\begin{array}{c}\text { Cr prior } \\
\text { to Co }\end{array}$} \\
\hline & & & ${ }^{14} \mathrm{C}$ & $\mathrm{Cr}$ & $\mathrm{Cr}$ & ${ }^{14} \mathrm{C}$ & ${ }^{14} \mathrm{C}$ & Co & Co & ${ }^{14} \mathrm{C}$ & Co & $\mathrm{Cr}$ & $\mathrm{Cr}$ & Co \\
\hline \multirow{6}{*}{ 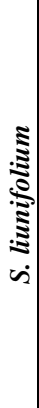 } & \multirow{3}{*}{ 先 } & U & 88.5 & 77.3 & 79.0 & 86.1 & 86.7 & 73.0 & 81.0 & 88.3 & 85.7 & 89.1 & 89.0 & 86.2 \\
\hline & & $\Sigma$ & 11.4 & 22.6 & 20.9 & 10.8 & 13.2 & 26.9 & 19.9 & 11.6 & 14.2 & 10.8 & 10.9 & 13.7 \\
\hline & & $\varangle$ & 7.7 & 3.42 & 3.77 & 8.20 & 6.53 & 2.71 & 4.06 & 7.61 & 6.02 & 8.21 & 8.15 & 6.29 \\
\hline & \multirow{3}{*}{ 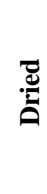 } & 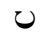 & 95.8 & 89.1 & 87.5 & 96.8 & 95.0 & 88.6 & 88.4 & 96.0 & 90.0 & 88.1 & 89.0 & 88.0 \\
\hline & & $\Sigma$ & 4.14 & 10.8 & 12.5 & 3.18 & 4.98 & 11.3 & 11.5 & 3.92 & 10.0 & 11.8 & 10.9 & 11.9 \\
\hline & & $\varangle$ & 23.1 & 8.21 & 7.00 & 30.4 & 19.0 & 7.83 & 7.63 & 24.5 & 9.00 & 7.46 & 8.13 & 7.39 \\
\hline \multirow{6}{*}{ 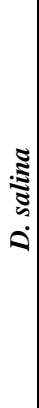 } & \multirow{3}{*}{ :ב } & 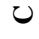 & 90.5 & 86.5 & 88.0 & 87.8 & 90.6 & 87.2 & 87.7 & 88.9 & 89.4 & 86.0 & 87.7 & 87.9 \\
\hline & & $\Sigma$ & 9.47 & 13.4 & 11.9 & 12.2 & 9.31 & 12.7 & 12.2 & 11.0 & 10.5 & 13.9 & 12.2 & 12.0 \\
\hline & & $\varangle$ & 9.56 & 6.42 & 7.38 & 7.20 & 9.74 & 6.85 & 7.16 & 8.06 & 8.51 & 6.19 & 7.15 & 7.29 \\
\hline & \multirow{3}{*}{ ق } & 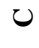 & 82.5 & 84.3 & 81.1 & 83.3 & 83.0 & 81.1 & 79.9 & 81.4 & 80.9 & 82.0 & 82.5 & 80.0 \\
\hline & & $\sum$ & 17.4 & 15.6 & 18.8 & 16.6 & 16.9 & 18.8 & 20.0 & 18.5 & 19.0 & 17.9 & 17.4 & 19.9 \\
\hline & & $\varangle$ & 4.74 & 5.39 & 4.31 & 5.02 & 4.90 & 4.31 & 3.98 & 4.38 & 4.26 & 4.56 & 4.73 & 4.02 \\
\hline
\end{tabular}

$\mathrm{C}=$ Cells; $\mathrm{M}=$ Medium; $\mathbf{A}=$ Accumulation ratio 
Pre-addition of ${ }^{14} \mathrm{C}$ to cobalt negatively affected its accumulation ratio (2.71), in case of adding ${ }^{14} \mathrm{C}$ after $\mathrm{Co}$; cobalt improved ${ }^{14} \mathrm{C}$-ratio and also its ratio was enhanced (4.06, 7.61 for Co prior to $\left.{ }^{14} \mathrm{C}\right)$.

Chromium-cobalt interaction was masked perhaps by the effect of ${ }^{14} \mathrm{C}$ which is taken up by the cells to enter the photosynthetic metabolic pathway, through which it counteracted the effect of other metals. Amado filho et al. (1999) postulated that metals were mainly adsorbed on the outer surface of the living algal cell on the basis of the free ion activity.

In dried Sargassum material, there was an increase in accumulation ratios with all the treatments used. The least accumulation ratio ranged from 8.21 to 7.00. This again spots the light on the free ion activity hypothesis of algal surface. The above results indicated that: dried cells of Sargassum had high adsorption power for ${ }^{14} \mathrm{C}$ with less efficiency for chromium and cobalt.

In Sargassum stenophyllum, the cell wall played the main role in cadmium accumulation. The release of metals by this alga has been frequently associated with exudation of metal chelated to polyphenolic compounds known to be present in this genus (Amado filho et al., 1999). In this investigation, Sargassum linifolium showed also a great sorption capacity for ${ }^{14} \mathrm{C}$, Co and $\mathrm{Cr}$ (especially for ${ }^{14} \mathrm{C}$ ) in both one-metal and two-metal systems, suggesting that they are suitable biosorbant for the treatment of water containing these radionuclides. Sorption activity was shown to be dependent on the initial ion concentration but not on the valency of the metal. However, the lower binding capacity for cobalt (by this alga) may be due to functional binding sites with low cobalt biosorbant on its surface.

Phillips (1990) concluded that the initial rapid uptake of an element would be corresponding to extracellular adsorption and/or to passive intracellular uptake (metabolism-independent) involving cell surface adsorption and simple diffusion into cells or intercellular spaces. A slower uptake will be corresponding to metabolism-dependent incorporation in the cell body. Teresa et al. (2001) also supported this postulation. On the contrary, Shafik (1993) found that the metabolism of ${ }^{14} \mathrm{C}$-urea by Sargassum linifolium was very fast, since the takenup ${ }^{14} \mathrm{C}$-urea found its way to protein and free amino acids within $1 \mathrm{~min}$ of incubation, i.e. fast uptake may also lead to metabolic- dependent biosorption.

In Dunaliella (Table 2), living cells exceeded the non-living cells in the determined accumulation ratios of the three elements. In living Dunaliella, the accumulation ratios for ${ }^{14} \mathrm{C}$ was the highest among the three tested elements, since, it reached the value of 9.74. Again, this is perhaps according to the counteracting effect of ${ }^{14} \mathrm{C}$ for both cobalt and chromium and its enhancing effect on photosynthesis. The interaction between the three nuclides in living cells of Dunaliella resembles that of living Sargassum dependent on the free ion activity. In dried Dunaliella cells, the accumulation ratios were almost constant independent of the valency of the metal. The surface area for dried Dunaliella was decreased to about $85 \%$ of its living value (Table 6 ). 
The effect of ${ }^{14} \mathrm{C}$, Co and $\mathrm{Cr}$ at different concentrations on chlorophyll contents was shown in Table $3 .{ }^{14} \mathrm{C}$ - uptake by living cells of Sargassum and Dunaliella ameliorated cell vitality i.e. increased the total chlorophyll contents and kept the chlorophyll ratios constant when different concentrations of ${ }^{14} \mathrm{C}$ were used. The effect of ${ }^{14} \mathrm{C}$ on Sargassum exceeded that of Dunaliella. In Sargassum, an $8.67 \mathrm{mg} / \mathrm{g}$ increase in total chlorophyll content was obtained when $15 \mathrm{mg} / \mathrm{L}{ }^{14} \mathrm{C}$ was used; chlorophyll $a$ alone was amounted to 70 percent of this value. Chlorophyll $a / c$ ratio remained almost constant (with the various concentrations used) and equal to the control, which indicated that stable metabolism was attended in presence of ${ }^{14} \mathrm{C}$ in Sargassum. In Dunaliella chl a/b ratio in ${ }^{14} \mathrm{C}$-treated living cells was almost constant, with a little decrease than the control but still in the range of $\mathrm{C}_{3}$ plants ( \pm 3 ). A steady increase in chl $a$ and $b$ of Dunaliella with various ${ }^{14} \mathrm{C}$ concentrations was obtained.

Table (3): Effect of different concentrations of ${ }^{14} \mathrm{C}$, $\mathrm{Co}$ and $\mathrm{Cr}$ on chlorophyll contents in both Sargassum linifolium and Dunaliella salina . Values are $\mathrm{mg} / \mathrm{g}$ fresh wt.

\begin{tabular}{|c|c|c|c|c|c|c|c|c|c|c|c|}
\hline \multirow{2}{*}{ 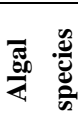 } & \multirow[b]{2}{*}{ Pigment } & \multirow[b]{2}{*}{ Control } & \multicolumn{3}{|c|}{${ }^{14} \mathrm{C}$} & \multicolumn{3}{|c|}{ Co } & \multicolumn{3}{|c|}{$\mathbf{C r}$} \\
\hline & & & 5 & 10 & 15 & 5 & 10 & 15 & 5 & 10 & 15 \\
\hline \multirow{4}{*}{ 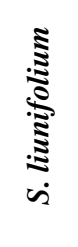 } & Chl $a$ & 2.71 & 5.14 & 7.38 & 8.73 & 2.25 & 2.10 & 1.68 & 1.93 & 1.84 & 1.53 \\
\hline & Chl $c$ & 1.23 & 2.34 & 3.32 & 3.88 & 1.07 & 1.02 & 0.97 & 1.00 & 0.93 & 0.86 \\
\hline & Total & 3.94 & 7.48 & 10.70 & 12.61 & 3.32 & 3.12 & 2.65 & 2.93 & 2.77 & 2.39 \\
\hline & $a / c$ & 2.20 & 2.19 & 2.22 & 2.25 & 2.10 & 2.06 & 1.73 & 1.93 & 1.98 & 1.78 \\
\hline \multirow{4}{*}{ 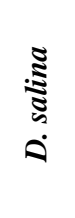 } & Chl $a$ & 6.14 & 11.32 & 12.56 & 12.71 & 5.43 & 5.53 & 4.79 & 5.80 & 5.39 & 5.12 \\
\hline & Chl $b$ & 1.75 & 4.00 & 4.80 & 5.02 & 1.31 & 1.51 & 1.04 & 1.21 & 1.43 & 1.30 \\
\hline & Total & 8.89 & 15.32 & 17.36 & 17.73 & 6.74 & 7.04 & 5.83 & 7.01 & 6.82 & 6.42 \\
\hline & $a / b$ & 3.51 & 2.83 & 2.62 & 2.53 & 4.14 & 3.66 & 4.61 & 4.79 & 3.77 & 3.93 \\
\hline
\end{tabular}

In Sargassum (Table 3) there was a little decrease in both chl $a$ and $c$ with 5 and $10 \mathrm{mg} / \mathrm{L}$ cobalt; a sharp decrease was attended with $15 \mathrm{mg}$ of cobalt. Treatment of algal cells with $15 \mathrm{mg}$ cobalt (in vitro) decreased the total chlorophyll contents by 33\%; the chl a/c ratio was decreased to 79 percent of the control value. In Dunaliella, a steady decrease in chl $a$ with the increase in cobalt concentration was obtained. In spite of that chl $b$ content remained almost constant and very close to the control; the $a / b$ ratio of the cobalt-treated Dunaliella was increased by 0.18 -fold the control value.

Chromium showed adverse effect on cell vitality even at low concentrations. High concentrations of chromium (10 and $15 \mathrm{mg} / \mathrm{L})$ caused a 
disorder in chl $a / b$ ratios. In Sargassum (Table 3), the decrease was amounted to $26 \%, 30 \%$ and $40 \%$ in the total chlorophyll content with 5,10 and $15 \mathrm{mg} / \mathrm{L}$ chromium respectively, the ratio of chl a/c was 1.9. In Dunaliella, although there was a little decrease in both chl $a$ and $b$ values, the $a / b$ ratio showed a little increase ( 1.36 fold the control value) with $5 \mathrm{mg} \mathrm{Cr}$ and decreased again with 10 and $15 \mathrm{mg}$ to reach the control ratio (Amorim et al., 2003).

Although the effect of ${ }^{14} \mathrm{C}$ on cell vitality was insignificant, it is the most hazardous material when present in lakes or sea water because it enters the metabolic pool of cell constituents of the biological individuals (Bassham and Calvin, 1957). The dangerous effects come from using living cells for ${ }^{14} \mathrm{C}$ removal, because no availability for desorption process for this radionuclide. In case of radio contamination of water sources with ${ }^{14} \mathrm{C}$, dried Sargassum cells is preferred to be used as biosorbant.

Table 4 shows the results obtained for the calculation desorption mechanism by the two investigated algae. $\mathrm{Q}_{\text {ads }}$ and $\mathrm{Q}_{\text {des }}$ differed considerably for the three tested elements. $\mathrm{Q}_{\mathrm{ads}}$ for Sargassum was less than the corresponding value for Dunaliella, while $\mathrm{Q}_{\text {des }}$ for Sargassum exceeded that of Dunaliella. Volesky and Kuyucak (1988) concluded that the theoretical calculations of desorption coefficient did not fit well with the true experimental results obtained so, another desorption parameters will be tried, depending on surface area calculation (Table 5).

Table (4): Desorption kinetics of ${ }^{14} \mathrm{C}$, Co and $\mathrm{Cr}$ from Sargassum and Dunaliella. Eluents were $\mathrm{NaOH}(0.1)$ for ${ }^{14} \mathrm{C}$; $\mathrm{HCl}(0.05 \mathrm{M})$ for $\mathrm{Co}$ and $\mathrm{H}_{2} \mathrm{SO}_{4}(0.6 \mathrm{M})$ for $\mathrm{Cr}$. Elution periods 3 and 6 hours.

\begin{tabular}{|c|c|c|c|c|c|c|c|c|c|}
\hline \multirow{2}{*}{ Nuclides } & \multirow{2}{*}{$\begin{array}{c}\text { Elution } \\
\text { time } \\
(\mathbf{h})\end{array}$} & $\mathbf{C}_{\mathrm{i}-\mathbf{C}_{\mathbf{f}}}$ & $\mathbf{Q}_{\text {ads }}$ & $\mathbf{C}_{\text {des }}$ & $\mathbf{Q}_{\text {des }}$ & $\mathbf{C}_{\mathrm{i}}-\mathbf{C}_{\mathbf{f}}$ & $\mathbf{Q}_{\text {ads }}$ & $\mathbf{C}_{\text {des }}$ & $\mathbf{Q}_{\text {des }}$ \\
\cline { 3 - 11 } & 3 & 124.0 & 28.5 & 12.80 & 6.90 & 210.00 & 48.27 & 10.30 & 3.12 \\
\hline \multirow{2}{*}{${ }^{14} \mathbf{C}$} & 6 & 400.00 & 20.00 & 13.58 & 7.20 & 213.00 & 10.65 & 10.93 & 4.50 \\
\hline \multirow{2}{*}{$\mathbf{C o}$} & 3 & 133.00 & 47.9 & 12.49 & 5.90 & 262.00 & 94.36 & 8.31 & 2.05 \\
\cline { 2 - 11 } & 6 & 135.00 & 82.4 & 12.42 & 5.60 & 246.00 & 150.15 & 9.07 & 2.70 \\
\hline \multirow{2}{*}{$\mathbf{C r}$} & 3 & 304.00 & 23.7 & 11.36 & 4.28 & 284.00 & 115.56 & 7.35 & 2.14 \\
\cline { 2 - 10 } & 6 & 1.47 & 62.85 & 12.85 & 5.19 & 299.00 & 127.13 & 8.84 & 3.23 \\
\hline
\end{tabular}

Table 5: Total surface area (S.A) of Sargassum linifolium and Dunaliella salina.

\begin{tabular}{|c|c|c|}
\hline & Sargassum linifolium & Dunaliella salina \\
\hline Water contents \% & 74.60 & 85.08 \\
\hline Total S.A mm $2 / \mathrm{mg}$ fresh wt. & ---- & 48.50 \\
\hline Total S.A mm $/ \mathrm{mg}$ dry wt & 2.83 & 7.24 \\
\hline
\end{tabular}


The results in Table 6 indicated that the desorption mechanism was faster with Sargassum alga than with Dunaliella. The desorption efficiency $\left(\% \mathrm{C}_{2} / \mathrm{C}_{1}\right)$ exceeded $90 \%$ for the three tested nuclides. Maximum $\mathrm{C}_{2} / \mathrm{C}_{1}$ ratio was attended with three hours of elution, and remained almost constant till 6 hours with the nuclide adsorbed by Sargassum. With Dunaliella a slow removal mechanism was obtained, since there was an increase in the efficiency through 6 hours of elution. On the average, only $82 \%, 70 \%$ and $67 \%$ desorption efficiency were obtained for ${ }^{14} \mathrm{C}$, Co and $\mathrm{Cr}$ adsorbed by Dunaliella, respectively.

The results in Table 4 indicated that the adsorbed materials on Sargassum surface were independent on the valency, this means equal distribution of exchanged anions on the surface of this alga. This is not the case with Dunaliella; least efficiency was obtained with chromium after 3 hours elution, with $\mathrm{H}_{2} \mathrm{SO}_{4}$, followed by cobalt (after 3 hour) and the maximum was obtained with ${ }^{14} \mathrm{C}$ after 6 hours elution period.

In Table 7, the maximum number obtained for elution of radionuclide from algal cell walls were five cycles for dried Sargassum cells and only three cycles for the Dunaliella.

With Sargassum linifolium, desorption efficiency was decreased to about $61 \%$ of the first cycle value after five cycles of cobalt elution. With chromium and ${ }^{14} \mathrm{C}$, the least values obtained were about $47 \%$ and $54 \%$, respectively, at the end of the fifth elution cycle. In Dunaliella, the amounts obtained after the second and third cycles were close to that of Sargassum with Co and Cr. ${ }^{14} \mathrm{C}$ amounted to $26 \%$ desorption efficiency. No availability for a fourth elution cycle with Dunaliella, supposing to be surface characteristics.

It is clear from the results in Table 8 that the adsorptive power of the living algae used was increased when grown on iron - deficient medium. With Sargassum linifolium, the increase was amounted to 5.02\%, 3.90\% and 3.10\% for ${ }^{14} \mathrm{C}, \mathrm{Cr}$ and $\mathrm{Co}$, respectively. With Dunaliella, these amounts were smaller, compared to Sargassum. The high adsorption occurred in presence of siderophore in Dunaliella was for chromium (3.3\%). These results indicated that siderophore formation was greater in macroalgal cell surfaces than in microalgae; siderophores possessed greater affinity for ${ }^{14} \mathrm{C}$ and $\mathrm{Cr}$ than $\mathrm{Co}$. These results indicated that: since siderophore formation was high in macroalgae than in microalgae, iron-deficient media for the growth of macroalgae, especially the brown, must be used as biosorbant to increase their adsorptive power for ${ }^{14} \mathrm{C}$ and Cr III.

Macroalgae are good biosorbant, as a result of their metal binding properties (Phillips, 1990), they have a high capacity to bind trace metals and radionuclide. Their cell wall is rich in sulphated polysaccharides hydroxyl sulphate. Hydroxyl sulphate and carboxyl groups of the polysaccharides are strong ion-exchangers, due to having complexation sites for hard and/or transition metal cations (Manley, 1984; Teresa et al., 2001; Liu et al., 2002; Tien, 2002). 
Radionuclide and Metal bioremediation from aquatic environment by algae

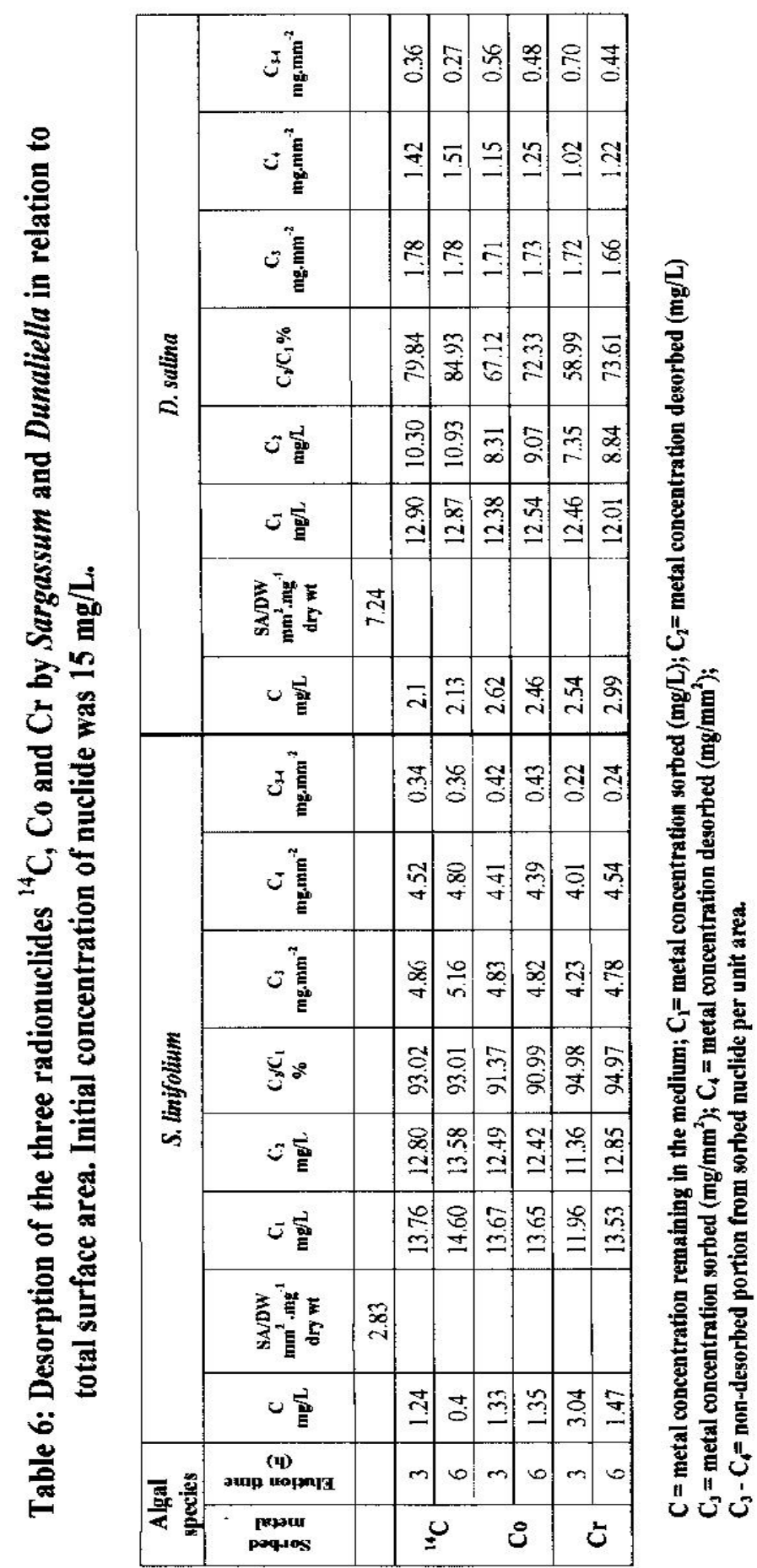


Table 7: Cycles of desorption processes carried out for $S$. linifolium and D. salina dry algal cells. Values obtained after 6 hours elution.

\begin{tabular}{|c|c|c|c|c|c|c|c|c|}
\hline $\begin{array}{c}\text { Algal } \\
\text { species }\end{array}$ & \multicolumn{5}{|c|}{ S. linifolium } & \multicolumn{3}{c|}{ D. salina } \\
\hline $\begin{array}{c}\text { Cycles } \\
\text { Nuclide }\end{array}$ & $1^{\text {st }}$ & $2^{\text {nd }}$ & $3^{\text {rd }}$ & $4^{\text {th }}$ & $5^{\text {th }}$ & $1^{\text {st }}$ & $2^{\text {nd }}$ & $3^{\text {rd }}$ \\
\hline${ }^{14} \mathrm{C}$ & 93.01 & 67.18 & 53.37 & 51.46 & 39.50 & 84.93 & 65.78 & 58.75 \\
\hline $\mathrm{Co}$ & 90.99 & 62.56 & 50.45 & 45.32 & 30.36 & 72.33 & 54.49 & 23.07 \\
\hline $\mathrm{Cr}$ & 94.97 & 63.88 & 52.80 & 50.21 & 48.02 & 73.61 & 48.13 & 35.56 \\
\hline
\end{tabular}

Table 8: Siderophore effect on the adsorption of ${ }^{14} \mathrm{C}$, Co and $\mathrm{Cr}$ by S. linifolium and $D$. salina living algal material, after 36 hours exposure to the nuclide.

\begin{tabular}{|c|c|c|c|c|c|c|c|c|c|}
\hline \multirow{2}{*}{$\begin{array}{c}\text { Algal } \\
\text { species }\end{array}$} & \multicolumn{3}{|c|}{${ }^{14} \mathbf{C}$} & \multicolumn{3}{c|}{ Co } & \multicolumn{3}{c|}{ Cr } \\
\cline { 2 - 11 } & $\mathbf{t}_{\mathbf{1}}$ & $\mathbf{t}_{\mathbf{2}}$ & $\mathbf{t}_{\mathbf{2}}-\mathbf{t}_{\mathbf{1}}$ & $\mathbf{t}_{\mathbf{1}}$ & $\mathbf{t}_{\mathbf{2}}$ & $\mathbf{t}_{\mathbf{2}}-\mathbf{t}_{\mathbf{1}}$ & $\mathbf{t}_{\mathbf{1}}$ & $\mathbf{t}_{\mathbf{2}}$ & $\mathbf{t}_{\mathbf{2}}-\mathbf{t}_{\mathbf{1}}$ \\
\hline S. linifolium & 89.80 & 94.82 & 5.02 & 82.14 & 85.24 & 3.10 & 80.40 & 84.30 & 3.90 \\
\hline D. salina & 91.00 & 93.70 & 2.70 & 87.70 & 89.77 & 2.07 & 87.50 & 90.80 & 3.30 \\
\hline
\end{tabular}

$\mathbf{t}_{1}=$ total sorbed nuclide in absence of siderophore $(\%)$

$\mathbf{t}_{2}=$ total sorbed nuclide in presence of siderophore $(\%)$

$t_{2}-t_{1}=\%$ increase in sorption power due to siderophore formation

A proposal for overall biosorption process in this investigation for the two algal species used is presented in scheme 1 .

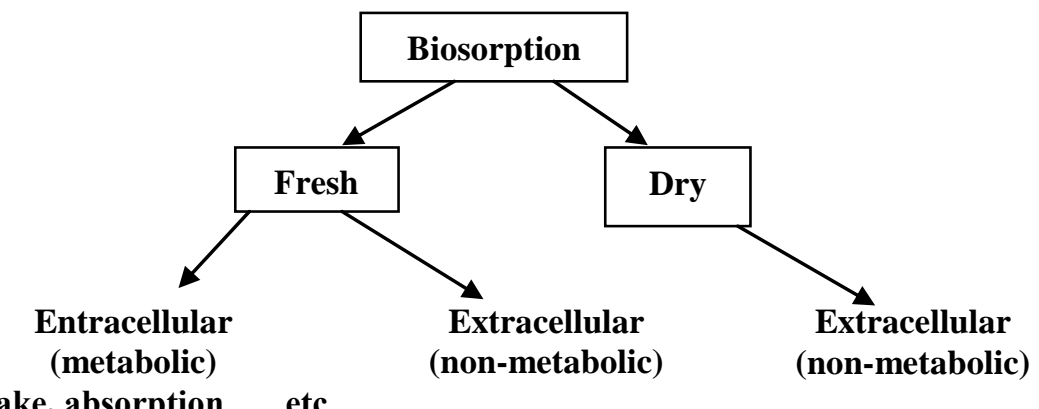

Uptake, absorption .....etc

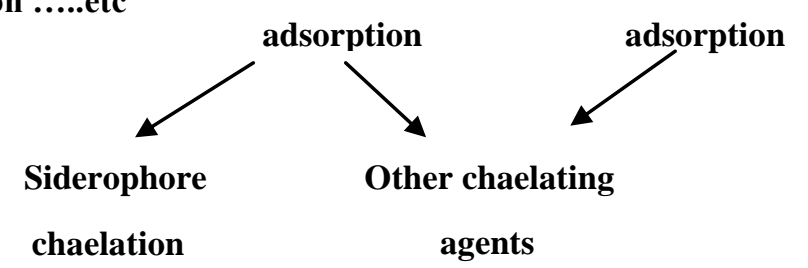

Scheme 1: A suggested proposal for the biosorption process in this investigation for the two algae used, either fresh or dry. 
Proteins, lipids and nucleic acids may also exist on the surface of the macroalgae cellular wall. The amine, carboxyl, imidazole, thiol, thioester and the nitrogen and oxygen of the peptidic bindings are thought to be responsible for the metal ions co-ordination in the cell body (Majidi et al., 1990).

The results of this investigation indicated the suitability of Sargassum and Dunaliella as biosorbant, suggesting that they can be used for the treatment of water containing chromium, cobalt and ${ }^{14} \mathrm{C}$ radionuclide in both one and two sorption systems. In spite of that, living microalga as Dunaliella outperforms nonliving microalga in its biosorbant capacity; the dry-non-toxic alga could also be used successfully as a safe biofilter for radioactive chromium and cobalt removal from lakes, but insufficient for ${ }^{14} \mathrm{C}$. Periodic harvesting of biosorbant microalgae could sustain the growth rate for a self-regenerating, remediation system (Terry and Stone, 2002). Desorption mechanism would then be applied for the recycling of biosorbant alga.

\section{References}

Akhtar, N.; Iqbal, J. and Iqbal, M. (2004). Removal and recovery of nickel (II) from aqueous solution by loofa sponge-immobilized biomass of Chlorella sorokiniana: characterization studies. J. Hazard. Mater., 108: 85-94.

Amado filho, G. M.; Andrade, L. R.; Karez, C. S.; Farina, M. and Pfeiffer, W.C. (1999). Brown algae species as biomonitors of $\mathrm{Zn}$ and $\mathrm{Cd}$ at Sepetiba Bay, Rio de Janeiro, Brazil. Marine Environ. Res., 48 (3): 213-224.

Amorim, W. B.; Hayashi, M. A.; Pimentel, P. F. and Silva, M. G. (2003). A study of the process of desorption of hexavalat chromium. Braz. J. Chem. Eng. 20 (3): 213-227.

Bassham, J. A. and Calvin, M. (1957). The path of carbon in photosynthesis. prentice-Hall, Englewood Cliffs, New Jersey, USA.104pp

Bekheet, L. A. and Syrett, P. J. (1977). Urea-degrading enzymes in algae. Brit. Phycol. J., 12: 137-143.

Bekheet, I. A.; Barakat, S.Y.; Shaalan, S.H. and Shafik, M. A. (1984). Effect of nitrogen source on the uptake of urea by Scenedeumus obliquus. Com. Sci. Dev. Res., 7: 203-215.

Centinkaya Donmez, G.; Aksu, Z.; Ozturk, A. and Kutsal, T. (1999): A comparative study on heavy metal biosorption characteristics of some algae. Process Biochem., 34: 885-892.

Chaisukant, Y. (2003). Biosorption of cadmium (II) and copper (II) by pretreated biomass of marine alga Gracilaria fisheri. Environ. Technol., 24:1501-1508.

Gadd, G. M. (1990). Heavy metal accumulation by bacteria and other microorganisms. J. Announcement. 46:834-840. 
Gazso, L. G. (2001). The key microbial processes in the removal of toxic metals and radionuclides from the environment. J. Chem. Tech. Biotechnol., 7(3-4): 178-185.

Halim, Y. (1987). Radiation pollution in the Mediterranean Sea. In: Symposium of Radiation Pollution. Alexandria Univ. Fac. Sci. Egypt. p20-25.

Jeffrey S. and Humphrey, G. (1975). New spectrophotometric equations for determining chlorophylls $\mathrm{a}, \mathrm{b}, \mathrm{c}$ and $\mathrm{c}_{2}$ in higher plants, algae and natural phytoplankton. Biochem. Physiol. Pflanzen (BPP). 167: 191-194.

Jones, R. F. (1960). The accumulation of nitrosyl ruthenium by fine particles and marine organisms. Limnol. Oceanog., 5: 312-325.

Liu, Y., Yang, S. F., Tan, S. F., Lin, Y. M. and Tay, J. H. (2002). Aerobic granules: a novel zinc biosorbent. Letters in Applied Microbiology. 35 (6): 548-551.

Loeblich, L. A. (1982). Photosynthesis and pigments influenced by light intensity and salinity in the halophilic Dunaliella salina (Chlorophyta). J. Mar. Biol. Ass. UK. 62: 493-508.

Majidi, J.; Majidi, D. and Holcombe, J. A. (1990). Investigation of the metal algae binding site with Cd nuclear magnetic resonance. Environ. Sci. Technol., 249: 1309-1312.

Manley, S. (1984). Micronutrient uptake and translocation by Sacroeystis phyrifer. J. Phycol, 20:192-201.

Masjuk, N. P. (1972). On phylogeny and taxonomy of the genus Dunaliella salina Teod. Ukranskya Botanichnya Zhornal. 29:744.

Neilands, J. B. (1983): Siderophores. In: Advances in Inorganic Biochemistry. Vol.5. (L. Eichlorn and L. G. Marzilli, eds). Elsevier, North Holland, Amsterdam, pp. 137-166.

Pena-Castro, J.; Martinez-Jeronimo, F.; Esparza-Garcia, F. and CanizaresVillanueva, R. (2004). Heavy metals removal by the microalga Scenedesums incrassatulus in continuous cultures. Bioresource Technology. 94 (2): 219-222.

Phillips, D. (1990). Use of macroalgae and invertebrates as monitors of metal levels in estuaries and coastal waters. In: Furness, R. W. and Rainbow, P. S., Editors Heavy Metals in the Marine Environment, CRC Press, Boca Raton, FL, USA, pp. 81-99.

Price, L.W. (1983). The radioactivity counting handbook. Cambridge University

Rice, T.R. and Willis, V.A. (1959). Uptake, accumulation and loss of radioactive cesium-134 by marine planktonic algae. Limnol. Oceanog., 4: 277-290.

Saleh, A. M. (1987). Radiopharmaceuticals: uses and hazards. In: Symposium of Radiation Pollution. Alexandria Univ. Fac. Sci. Egypt. p32-38.

Shaban, N. Z. (1981). Biochemical studies of urea-degrading enzymes in green algae. M.Sc. Thesis, University of Alexandria, Egypt. 145pp. 
Shafik, M.A. (1993). ${ }^{14} \mathrm{C}$-urea metabolism by some marine algae from Alexandria in combination with sewage treatment. Egypt J. Appl. Sci., 8(10): 275-303.

Shafik, M. and Alaa, A. (1995). Nitrogen and phosphorus removal from industrial woolemater by the unicellular green alga Scenedesnus obliquus. Egypt. J. Appl. Sci., 10 (12): 307-319.

Spooner, G. M. (1949). Observations on the absorption of radioactive strontium and ruthenium by marine algae. J. Marine Bio. Ass., 28: 587-625.

Teresa, M.S.; Vasconcelos, D. and Fernanda, M. C. (2001). Seasonal variability in the kinetics of $\mathrm{Cu}, \mathrm{Pb}, \mathrm{Cd}$ and $\mathrm{Hg}$ accumulation by macroalgae. Marine Chemistry. 74 (1): 65-85.

Terry, P. A. and Stone, W. (2002). Biosorption of cadmium and copper contaminated water by Scenedesmus abundans. Chemosphere. 47: 249-255.

Tien, C. J. (2002): Biosorption of metal ions by freshwater algae with different surface characteristics. Process Biochem. 38: 605-613.

Valdmar, E. and Leite, S. (2000). Biosorption of Cal, Zn and Cu by Sargassum sp. waste biomass. Bioprocess Engineering. 22: 171-173.

Vilar, V. J.; Botelho, C. M. and Boaventura, R. A. (2007). Copper desorption from Glidium algal biomass. Water Research. 41(7): 1569-1579.

Volesky, B. and Kuyucak, N. (1988). Desorption of Cobalt-laden Algal. Biosorvent, Biotechnology and Bioengineering. 33: 815-822.

Yang, J. and Volesky, B. (1999). Cadmium biosorbtion rate in prolonated Sargassum biomass. Environ. Sci. Technol., 33:751-757. 


\title{
تثقية مياه البحار والبحيرات من المواد المشعة و المعادن باستخدام

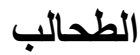

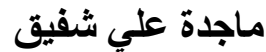

\author{
قسم العلوم البيولوجية والجيولوجيا- كلبة التربية - جامعة الإسكندرية. ج.م.ع
}

بطرح هذا البحث حلا بيولوجيا لتخليص مياه البحار و البحير ات من العناصر المشعة، وذلك إما

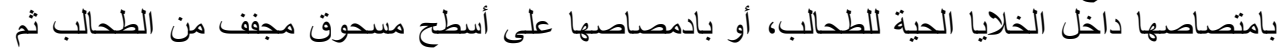

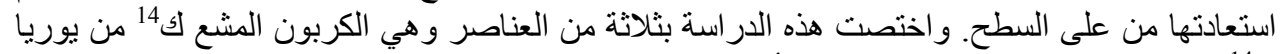

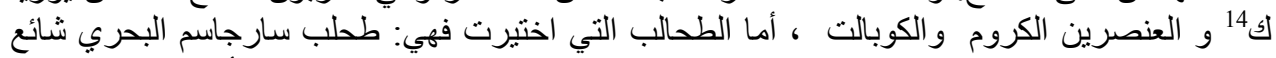

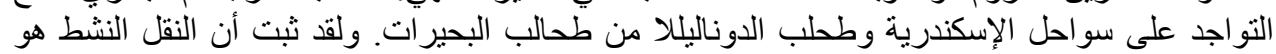

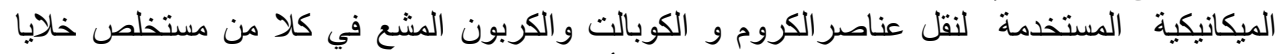

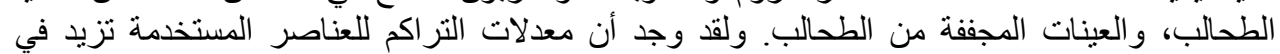

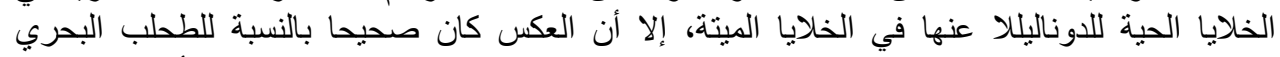

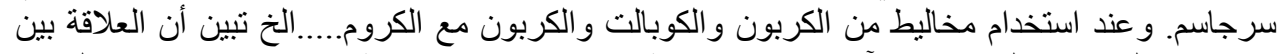

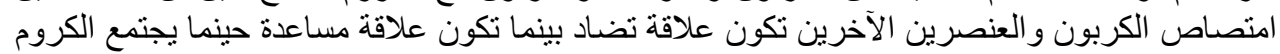

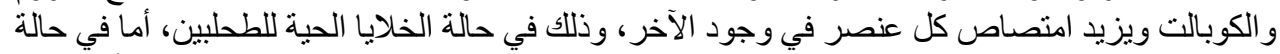

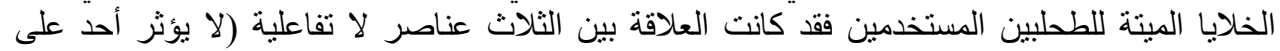

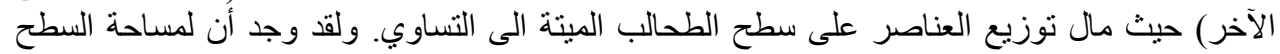

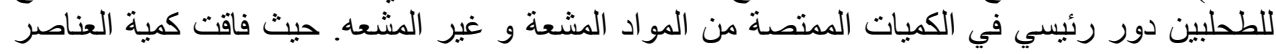

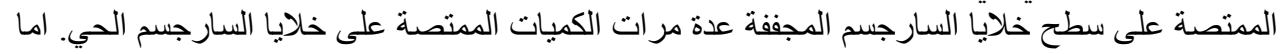

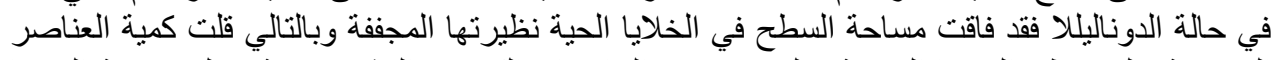

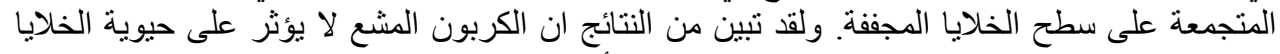

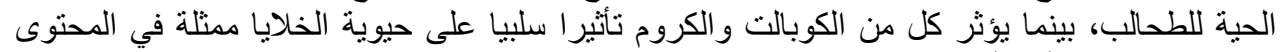

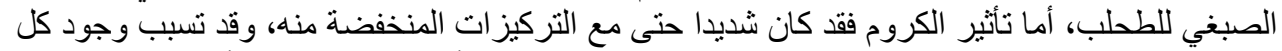

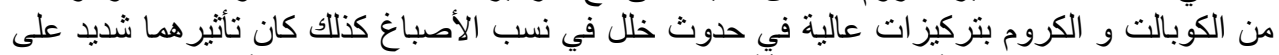

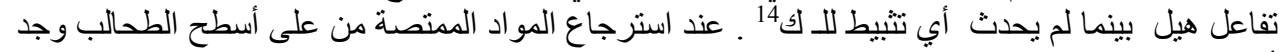

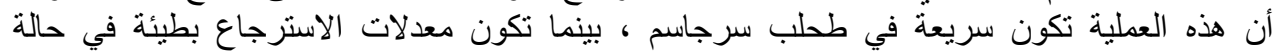

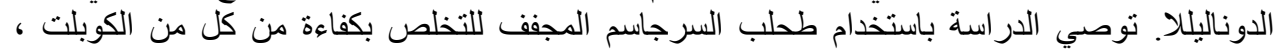
الكروم و الكربون المشع في حالة وجودها في مياه البحار ، خاصة إذا أمكن تجويعه من الحديد وزيادة مساحة الكادة 